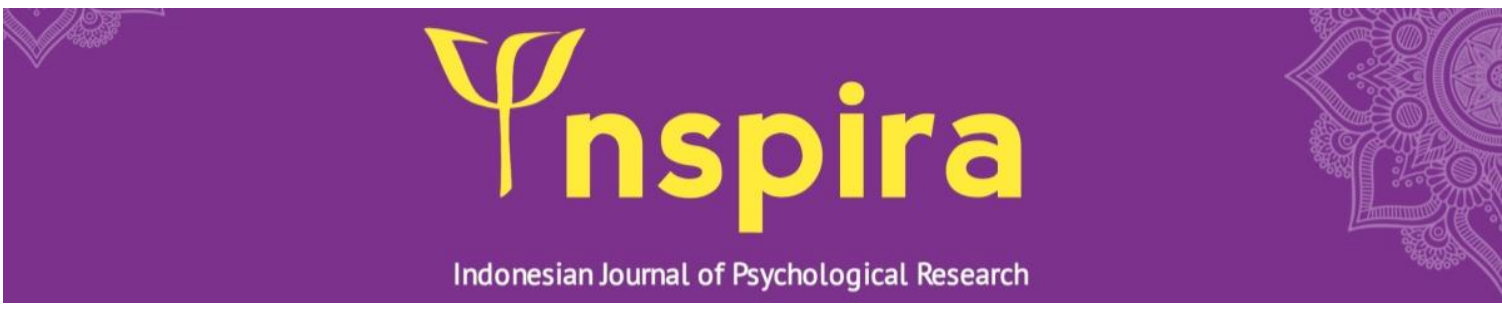

\title{
Empathy therapy to raise awareness of verbal bullying hazards
}

\author{
Dini Mai Hesty ${ }^{1}$, Dedy Surya ${ }^{2 \bowtie}$
}

${ }^{12}$ Department of Islamic Guidance and Counseling, Institut Agama Islam Negeri Langsa, Aceh, Indonesia.

$\bowtie$ Corresponding author:
Dedy Surya (email: dedysurya@iainlangsa.ac.id)
Abstract - The low awareness of verbal bullying hazard is caused by a low of empathy in individuals. Empathy therapy can be used to develop a sense of empathy, and it can raise awareness about verbal bullying hazard, thereby minimizing the tendency of verbal bullying. This study aims to see the effectiveness of empathy therapy for raised awareness of verbal bullying hazards. This research used a quantitative approach-quasi experimental (one group pretest-posttest design), with a purposive sampling technique, sample by six female participants between ages 17 and 19 in Gampong Paya Bujok Tunong. The instrument used in the research is the tendency scale of verbal bullying. The finding showed that there was a significant empathy therapy decreasing the tendency of verbal bullying.

\section{Article History:}

Received: Angust 30, 2020

Revised: September 10, 2020

Accepted: November 15, 2020

Published: December 28, 2020

\begin{tabular}{lll}
\hline Keyword: & \\
behavior; & bullying; empathy \\
awareness; & empathy & therapy;
\end{tabular}

verbal bullying

How to cite (APA $7^{\text {th }}$ Edition)

Hesty, D. M. \& Surya, D. (2020). Empathy therapy to raise awareness of verbal bullying hazards. INSPIRA: Indonesian Journal of Psychological Research, 1(2), 57-62. https://doi.org/10.32505/inspira.v1i2.2879 


\section{INTRODUCTION}

Bullying is a negative behavior, deviant, and dangerous behavior, which includes physical and verbal acts performed repeatedly to corner, alienate, threaten, and even harm the victim. Short-term bullying will lead to feelings of insecurity, lack of confidence, depression, or stress that can lead to suicide, while in the long run, it can lead to emotional and behavioral problems (Kurnia, 2018).

The highest incidence of bullying occurs in this type of verbal bullying; as revealed in Gitry Marela's research, $49 \%$ of adolescents experience bullying, which is more commonly experienced as verbal bullying because it is called by an unwelcome name and often ridiculed by peers (Marela, Wahab, \& Marchira, 2017).

Olweus explains verbal bullying is aggressive behavior with negative actions that use words (verbal) such as threatening, insulting, mocking, and calling an actual name (Olweus, 1993). Verbal bullying is also known as aggressive verbal behavior. The research conducted by Agung revealed that aggressive verbal behavior is a form of violence committed by someone by swearing, taunting, denouncing, or vilifying others by using words (Prasetya, Fauzi, \& Ramadhani, 2019).

Verbal bullying is more common because of the ejection of words such as giving a nickname or calling a peer with a call that is not often done in the school environment or the play environment. Without them realizing it, sometimes the calls harm the victim. National Centre Against Bullying (2019) also explains that forms of verbal bullying include name-calling, taunting, homophobic or racist remarks, insulting, intimidation, and verbal abuse.

At an international teacher education conference, Saripah (2010) explained that individual perpetrators of violence referring to bullying have low empathy abilities and high levels of aggressiveness. Perpetrators are happy to see others struggling or suffering. On the other hand, they show no guilt when committing acts of bullying, either physical or verbal.

Ickes (1993) describes empathy as the ability to understand other people's thoughts and feel how others feel. Empathy is brought on from the moment the child is born, but there is no guarantee whether it can understand the feelings of others well developed. (Borba, 2008). Dwi, in her research, revealed that bullying perpetrators have low empathy. The lack of empathy makes it difficult to see from the viewpoint of others and unable to understand the situation of the victim (Rachmah, 2016).

The phenomenon of bullying also occurs in the sphere of adolescent association in Gampong Paya Bujok Tunong, a phenomenon that is considered typical in this association turns out to have a psychological effect for the direct impact. According to a teenager, he is often ridiculed by his friends because he wears glasses when he goes to school. This resulted in being unconfident, not infrequently, because the taunts he took off his glasses caused him to lower his spirit to go to school and decrease the concentration of learning of the teenager. This event does not escape the unconsciousness of the perpetrator about how the circumstances, feelings, and dangers of the word affect the victim. one of the factors is that he does not position himself "what if it happens to me" or the lack of empathy that exists in the perpetrator.

In research conducted by Adinar and Miftahun, bullying tendencies can be minimized by providing therapy, which can be done, such as empathy therapy. Empathy therapy is a term used 
by researchers to experiment to develop empathy in a person; fostering empathy in an individual can reduce or decrease the tendency of bullying (Fatimatuzzahro \& Suseno, 2018)

According to Lika (2019), empathy therapy is a learning activity to foster the perpetrator's caring attitude in understanding the victim's feelings, thoughts, and points of view. This therapy emphasizes how an individual's thinking process can suppress the behavior (Lika, 2019). Pecukonis (1990) explained that empathy therapy is an experiment to develop and analyze empathy responses consisting of affective and cognitive abilities of the subject. The experimental group after empathy therapy had to undergo significant level changes from the control group.

Researchers found a negative correlation between low empathy and bullying tendencies and empathy therapy to increase empathy based on previous research literature studies. However, in Indonesia, research is still relatively rare about raising awareness about the dangers of verbal bullying tendencies in-depth; thus, researchers are interested in conducting research to find out if the use of empathy therapy is effective to raise awareness about the dangers of verbal abuse bullying. The study aims to investigate empathy therapy to raise awareness about the dangers of verbal bullying.

\section{RESEARCH METHOD}

This study uses a quantitative approach - quasi-experiment, the subject of the study is a resident in Gampong Paya Bujok Tunong, Kota Langsa. Sample recall techniques using purposive sample techniques, the sample criteria in this study are: aged 17-19 years and female gender, often appear desire in the subject to hurt others through his words. The subject is willing to fill out a statement (informed-consent) as a form of willingness to follow a series of stages in the implementation of the study until found six individuals as samples.

There are two variables used, namely the free variable (x) - empathy therapy and the bound variable (y) - verbal bullying. Data collection techniques are done with one group pretest-postest design techniques, and this technique is considered more effective to see the significance of the average difference of pre-test and post-test after being given treatment, i.e., empathy therapy. Therapy is done by providing auditory, visual, or kinesthetic stimulation (Pecukonis, 1990) so that individuals can increase empathy; in the implementation, researchers divided it into three sessions. The first session of individuals are invited to discuss, the second session of individuals are directed to watch a movie about the dangers of verbal bullying, and the third session of individuals are invited to exchange roles as others (roleplaying) to be able to feel their feelings directly. The instrument in this study is a scale of verbal bullying tendencies that researchers compiled based on Olweus's theory of verbal bullying (1993), with the design of the Likert scale using a favorable and unfavorable statement with alternative answers very appropriate, appropriate, neutral, inappropriate and wildly inappropriate. The higher the score, the higher the level of verbal bullying tendency of the individual, data processing on the research scale using the help of SPSS 22.0 application. The research scale consists of 21 statement items that have passed the validity test with a value above 0.514 and a Cronbach's Alpha value reliability test of 0.973, so this scale is immense. (Riduwan, 2010).

The data analysis technique in this study was a prerequisite test using the Shapiro Wilk normality test because the number of samples $<50$, as well as the hypothesis test used, was a 
paired sample t-test, to see a significant difference between pre-test and post-test after the subject was given empathy therapy.

\section{RESULT}

The categorization of verbal bullying tendencies is determined based on the acquisition of the number of scores based on data processed with SPSS version 22.0. This classification is based on a predetermined formula (Azwar, 2012), known minimum score (21), maximum score (105), range (84), mean/M (63), and standard deviation/SD (14).

Table 1. Categorization of interval score

\begin{tabular}{ccc}
\hline Norm & Score interval & Categorization \\
\hline $\mathrm{X}_{(\min )} \leq 63-1.5(14)$ & $21-42$ & Very Low \\
\hline $63-1.5(14) \leq 63-0.5(14)$ & $42-56$ & Low \\
\hline $63-0.5(14) \leq 63+0,5(14)$ & $56-70$ & Average \\
\hline $63+0.5(14) \leq 63+1,5(14)$ & $70-84$ & High \\
\hline $63+1.5(14) \leq \mathrm{X}_{(\max )}$ & $84-105$ & Very High \\
\hline
\end{tabular}

In Table 2, you can see the pre-test score before empathy therapy and post-test score after empathy therapy; four people sampled decreased verbal bullying tendency in the low category. Three sample people came from the moderate category and one person sampled from the high category, and two other sample people from the high category decreased to the very low category.

Table 1. Descriptive statistics

\begin{tabular}{ccccccccc}
\hline \multirow{2}{*}{ Sample } & \multicolumn{3}{c}{ Pre-test } & \multicolumn{5}{c}{ Posttest } \\
\cline { 2 - 8 } & M & SD & Score & Category & M & SD & Score & Category \\
\hline 1 & 3.14 & 0.573 & 66 & Average & 2.14 & 0.478 & 45 & Low \\
2 & 3.57 & 0.673 & 75 & High & 2.19 & 0.480 & 46 & Low \\
3 & 3.24 & 0.700 & 68 & Average & 2.33 & 0.483 & 49 & Low \\
4 & 3.48 & 0.680 & 73 & High & 1.95 & 0.129 & 41 & Very Low \\
5 & 3.29 & 0.717 & 69 & Average & 2.24 & 0.095 & 47 & Low \\
6 & 3.38 & 0.498 & 71 & High & 2.00 & 0.73 & 40 & Very Low \\
\hline
\end{tabular}

Furthermore, the prerequisite test in this study used the Shapiro Wilk p-value normality test. 0.05 using SPSS 22.0 application $((6)=0.955>\mathrm{p}=0.05)$ known normally distributed data. Hypothesis test in the study using paired sample t-test.

Tabel 3. Paired sample t-test

\begin{tabular}{cccc}
\hline Test & $\mathrm{M}$ & SD & SE \\
\hline Pretest & 70.33 & 3.327 & 1.358 \\
posttest & 45.17 & 2.858 & 1.167 \\
\hline
\end{tabular}

Based on table 3 shows that the mean value with six samples on the scale of verbal bullying tendency at the time of pre-test is 70.33 with a standard deviation of 3,327 and the standard error 
at 1,358 , then at the time of post-test obtained mean worth 45.17 with a standard deviation of 2,858 and error standard 1,167.

Table 4. Hypothesis test

\begin{tabular}{cccc}
\hline $\mathrm{M}$ & $\mathrm{t}$ & $\mathrm{df}$ & p-value \\
\hline 25.167 & 11.871 & 5 & $<0,001$ \\
\hline
\end{tabular}

Table 4 describes the difference between the mean pretest-posttest of 25,167 (17\%), and the value $\mathrm{t}(5)=11,871$.

\section{DISCUSSION}

The results of this experimental study prove the effectiveness of empathy therapy to raise awareness of the dangers of verbal bullying that researchers have done. Empathy therapy can develop empathy to raise awareness about the dangers of verbal bullying. These findings are supported by Inneke research (2018) that empathy therapy has the effect of lowering cyberbullying behavior. Another study belonging to Lika (2019) also showed that bullying tendencies decrease after being given treatment be a form of empathy therapy.

Age factors are also one reason responses are obtained in adolescent subjects faster. This aligns with Borba's theory (2008) that the more mature a person is, the cognitive and affective state also matures. This cognitive and affective maturity makes empathy develop well, as Davis's definition of empathy is how one can understand and feel the feelings of others. People who have empathy will be more sensitive and less likely to hurt others intentionally.

The treatment given to stimulate cognitive as well as affective subjects in empathy therapy makes the subject quickly respond to any stimuli given so that it easily evokes the emotional side as if the subject is feeling the emotions of others, supported by Izzah's research (2019) empathy training reacts to the feelings of others with their emotional responses. In empathy therapy, the emotional response is visible when screening a film about bullying. When emotional responses arise here, empathy is developing, and it constantly makes individuals aware of the dangers of verbal bullying.

In this study, researchers were limited to the development of empathy using empathy therapy. It is hoped that the researchers will further explore other variables that affect verbal bullying tendencies to expand the research sample and develop research using different data collection techniques.

\section{CONCLUSION}

From the results outlined in this study, it is known that empathy therapy influences the decrease in verbal bullying tendencies by $17 \%$. Using the t-test is known t-count values more significant than the $\mathrm{t}$-table value at $5 \%$ significance, so the proposed $\mathrm{Ha}$ is acceptable. Empathy therapy minimizes the level of verbal bullying tendencies. It was concluded that there were significant differences so that empathy therapy effectively lowered verbal bullying. 


\section{REFERENCES}

Azwar, S. (2012). Penyusunan skala psikologi (2nd ed.). Pustaka Pelajar.

Borba, M. (2008). Membangun kecerdasan moral: Tujub kebajikan utama untuk membentuk anake Bermoral tinggi (Raviyanto (ed.)). Gramedia Pustaka Utama.

Davis, M. H. (1983). Measuring individual differences in empathy: Evidence for a multidimensional approach. Journal of Personality and Social Psychology, 44(1), 113-126. https://doi.org/00223514763

Fatimatuzzahro, A., \& Suseno, M. N. (2018). Efektivitas terapi empati untuk menurunkan perilaku bullying pada anak usia sekolah dasar. Jurnal EMPATI, 6(3), 362-378. https://ejournal3.undip.ac.id/index.php/empati/article/view/19767

Ickes, W. (1993). Empathic accuracy. Journal of Personality, 61(4), 587-610. https://doi.org/10.1111/j.1467-6494.1993.tb00783.x

Izzah, L. \& Gusniarti, S. U. (2019). Pelatihan empati untuk menurunkan perilaku bullying pada pelaku bullying di sekolah dasar. Jumal Intervensi Psikologi, 11(2), 79-90. https://doi.org/10.20885/intervensipsikologi.vol11.iss2.art2

Kurnia, I. (2018). Bullying. Relasi Inti Media.

Kusheriyanti, I. (2018). Pengaruh pelatihan empati terbadap perilaku cyberbullying pada remaja. Universitas Islam Negeri Sunan Ampel. [Undergraduate thesis - Universitas Islam Negeri Sunan Ampel]

Lika, L. (2019). Pelatihan empati sebagai upaya mengurangi perilaku perundungan pada siswa SMP. Persona: Jurnal Psikologi Indonesia, 8(2), 308-324. https://doi.org/10.30996/persona.v8i2.2365

Marela, G., Wahab, A., \& Marchira, C. R. (2017). Bullying verbal menyebabkan depresi remaja SMA Kota Yogyakarta. Berita Kedokteran Masyarakat, 33(1), 43. https://doi.org/10.22146/bkm.8183

National Centre Against Bullying. (2019). Types of Bullying. https://www.ncab.org.au/bullyingadvice/bullying-for-parents/types-of-bullying/

Olweus, D. (1993). Bullying at school: What we know and what we can do. Blackwell.

Pecukonis, E. V. (1990). A Cognitive/affective empathy training program as a function of ego development in aggressive adolescent females. Adolescence, 25(97), 59-76.

Prasetya, A., Fauzi, T., \& Ramadhani, E. (2019). Pengaruh lingkungan terhadap perilaku agresif verbal siswa dalam berkomunikasi. ENLIGHTEN: Jurnal Bimbingan Konseling Islam, 2(2), 6873. https://doi.org/10.32505/enlighten.v2i2.1351

Rachmah, D. N. (2016). Empati pada pelaku bullying. Jurnal Ecopsy, 1(2). https://doi.org/10.20527/ecopsy.v1i2.487

Riduwan, R. (2010). Dasar-dasar statistika (Prama Dwija Iswara (ed.)). Alfabeta.

Saripah. (2010). Model konseling kognitif perilaku untuk menanggulangi bullying siswa, (Studi Pengembangan Model Konseling pada Siswa Sekolah Dasar di Beberapa Kabupaten dan Kota di Jawa Barat Tahun Ajaran 2008/2009). Proceedings of the 4th International Conference on Teacher Education; Join Conference UPI \& UPSI Bandung, Indonesia, $720-726$. 